\title{
A GESTAÇÃO DO ÚLTIMO ELDORADO BRASILEIRO (1961-1988)*
}

\author{
Elio Chaves Flores**
}

\section{INTRODUÇÃO}

"A sociedade capitalista aparece aos olhos vislumbrados do homem moderno como a realização acabada da história." (Raymundo Faoro)

A pesquisa em História Regional ${ }^{1}$ possibilita trabalhar a História a partir da "microfísica do poder" e dos diversos espaços que muitas vezes se

* Monografia realizada para a linha de pesquisa Estruturas de Poder e Classes Sociais no Norte Goiano (Tocantins) do Colegiado de História - COPN, a ser apresentada na SBPC, Seção História, em julho de 1994 em Vitória Espírito Santo.

** Professor Adjunto I/UNITINS/CUPN. Mestre em História Ibero-Americana PUC-RS.

1 As obras teórico-metodológicas que serviram de base para a análise do presente trabalho foram as seguintes: CARBONARI, Maria Rosa. "Algumas consideraçōes sobre o conceito de História Regional - Um enfoque teórico-metodológico." In: Veritas PUC-RS. Porto Alegre, jun-1991, 269-294; CARDOSO, Ciro F. História da Agricultura e História Regional. In: Agricultura, escravidão e capitalismo. Petrópolis: Vozes, 1982; LOBATO CORREA, Roberto. Região e organização espacial. São Paulo: Ática, 1986; WESTPHALEN, Cecília M. História Nacional, História Regional. In: Revista Estudos Brasileiros. Curitiba, n² 3, 1977; VIEIRA, Maria do Pilar de A. et al. A pesquisa em história. São Paulo: Ática, 1989. 
perdem no "todo" nacional, uma que, por falta de vinculaçōes teórico-metodológicas e documcntais ficam descontextualizados. É a partir da história regional que se torna possível entender os fenômenos sociais diferentes, originados em tempos históricos ora desreguladores, ora homogeinizadores de um determinado espaço social e produtivo.

A conjuntura brasileira pós-anos 60 constitui um período rico em transformaçōes político-sociais a nível nacional: crise, ruptura e banimento do populismo desenvolvimentista da órbita do governo e do próprio Estado (1961-1966); radicalização político-ideológica entre o setor burocrático-militar em vias de se tornar hegemônico e parte da sociedade civil, através de intelectuais liberais e de esquerda, estudantes, profissionais autônomos e operários contra o fechamento do regime (1967-1973); o fim do milagre econômico" e o conseqüente exaurimento do autoritarismo militar (19741983); e, por fim, emerge o processo de redemocratização do país consubstanciado no movimento das "Diretas já" em 1984 e reafirmado com a última Constituição (1984-1988). Assim, o centralismo burocrático-militar passa a ser substituído pela idéia de federação e maior responsabilidade política e social para os estados-membros.

Assiste-se, nessa conjuntura de média duração (1961-1988), ${ }^{2}$ a definitiva incorporação das grandes áreas do país (Amazônia legal e Cerrado) ao fluxo do capitalismo do Sul-Sudeste, projetando para aqueles áreas de grandes contingentes sociais em busca de novas oportunidades.

O crescimento das cidades e o fluxo populacional para as áreas incorporadas produzem novas aspirações individuais e coletivas, novas dinâmicas formas de ganhar a vida, assim como exige outros mecanismos de cooptação política. Lentamente, tal processo tende a modificar, inclusive, a metalidade dos segmentos dominantes de uma região periférica e secundária às decisões do próprio Estado como era o caso do norte goiano.

Se a realização autonomista do Tocantins, concretizada com a Assembléia Constituinte (1986-88), tinha fundamentos históricos inegáveis, julga-

2 Optou-se pela concepção braudeliana do tempo uma vez que ela revela a história das crises em que as estruturas e sua dinâmica são reveladas nas suas reentrâncias pelo tumulto dos acontecimentos conjunturais. Estes, bem entendido, são os movimentos a breve prazo que se debatem contra as permanências seculares. Cf. BRAUDEL, Fernand. História e Ciências Sociais. Lisboa: Presença, 1982; — . Escritos sobre a História. São Paulo, Perspectiva, 1978; LE GOFF, Jacques. Tempos breves, tempos longos. In: - O maravilhoso e o cotidiano no Ocidente Medieval. Lisboa: Ediçōes 70, 1985, p. 201-19. Ver ainda de LE GOFF, o excelente artigo Tempo, Trabalho e Cultura no Ocidente. In:Para um novo onceito de Idade Média. Lisboa: Estampa, 1980, p. 43-73. 
se necessário a análise da estrutura social do então norte goiano e, a partir daí, tentar demonstrar qual a tipologia mais adequada para concretizar as estuturas de poder no Cerrado contemporâneo. Em síntese, o problema está em saber quais os mecanismos de permanência do coronelismo regional e quais seriam as matizes do discurso liberal-populista na "modernização" parciaxl do Estado, para, enfim, tentar delinear a prática política e sua aplicabilidade subjacente nos órgãos de poder dos níveis estadual e municipal.

O impacto das mudanças econômicas na pirâmide social da região, deve colocar o Estado como real interessado na adoção de políticas públicas compativeis com a modernização regional. Assim, compreender e analisar os grupos que formam a sociedade regional torna-se uma necessidade intrínseca ao ato de governar e ao processo democrático.

Finalmente, o presente trabalho pretende colaborar para a construção da História do Tocantins, na medida em que seleciona e sistematiza um dado conjunto de fontes históricas e bibliográficas. Da mesma forma, pode abrir novas hipóteses de trabalho para os novos profissionais das ciências sociais.

\section{2 - O ESTADO BUROCRÁTICO E O CERRADO}

\section{1 - Os militares e o espaço regional}

É unanimidade na ciência política brasileira de que o regime pós-64 teve sérios entraves para solidificar a sua legalidade. Ainda que se admita que o populismo precedente tivesse chegado ao exaurimento por suas contradições inerentes, a nova situação institucional requeria um discurso legitimista. Este seria sustentado pela visão ideológica do Estado ocupado por técnicos competentes e por militares honestos. Tal imagem construída gerou a peculiaridade de que as Forças Armadas Brasileiras expressavam a legitimidade consentida e guardiã do novo regime. Essa singularidade projetou a conjuntura pós-64 para além do medo populista e reificou o Estado para implementar o chamado milagre econômico na década de $70 .^{3}$

A orientação dada ao desenvolvimento da economia brasileira no período do "milagre" - 1969-1973 -, acarretou um forte aumento dos custos de produção dos setores industrial, agrícola e de serviços. A rápida expansão

3 DREIFUSS, René A. 1964: a conquista do Estado. $3^{3}$ ed. Petrópolis-RJ, Vozes, 1981, p. 486 e nota 30 da conclusão, p. 494. 
econômica não foi acompanhada de uma deliberada ação social do Estado no sentido de alavancar o desenvolvimento social e distributivo. A preocupação estatal era a Segurana Nacional, cabendo às empresas transnacionais e ao capital privado autóctone a supremacia e busca de novos mecanismos de incorporação de pessoas e regiōes para as graças do milagre. Esses espaços novos em termos de inserção das leis de mercado, de seu meio ecológico e da população neles contida acabou gerando a degradação do meio natural que, se "em outras partes gera o freio malthusiano ou exige esfoxrço acumulativo e progresso técnico para contornar a barreira dos rendimentos decrescentes, compensada pela expansão do espaço econômico". ${ }^{4}$

Com a definitiva pavimentação da rodovia Belém-Brasília e a abertura de inúmeras estradas na região da Amazônia legal, governo militar intensifica a "nacionalização" do espaço do cerrado na órbita do capital financeiro ex industrial. Mesmo assim, conforme Nunes, "os desequilíbrios regionais não são superados pelas rodovias e, em certas áreas, elas tendem a acentuá-los." ${ }^{5}$

O crescimento econômico no período do milagre médici-delfiniano foi acompanhado ideologicamente por um tipo de "nacionalismo multi-mídia" com apelos patrióticos para que a população de todo o território nacional se sentisse a mesma e que tomasse para si a defesa da legitimidade do regime. Já as distorçōes e males sociais do "milagre" eram sufocados pela manipulação das informações, censura prévia, e pelo combate a oposição no forma de guerra ao inimigo interno. ${ }^{6}$

A geopolítica dos governos militares não prescindia das regiōes economicamente menos importantes para efetivar a manutenção do regime. Pelo contrário, foram as regiōes nordeste, centro-oeste e norte que, no colégio eleitoral, davam a sustentação política aos devidos objetivos dos sucessivos governos militares. O peso dessas regiōes devia-se a representação parlamentar de estado por estado e de $1 / 3$ do Senado biônico no decorrer das décadas de 70 e 80 . Amazônia legal, do ponto de vista geopolítico, era a "menina dos olhos" das preocupaçōes militares.

4 FURTADO, Celso. O Brasil Pós-Milagre. 7. ed. Rio de Janeiro: Paz e terra, 1982, p. 23.

5 NUNES, Helena P.A Era Rodoviária em Goiás; impactos na estrutura rural e urbana (1930-1961) Goiânia: UFG, Dissertação de Mestrado, 1984, p. 228.

6 Saflate enumera os motes ideológicos do qüinqüênio 1969-1973: "Ontem, hoje e sempre: Brasil"; "Brasil: ame-o ou deixe-o"; "Brasil: conte comigo"; "O Brasil marcha para o seu grande destino"; Ninguém segura este país". Cfe. SAFATLE, Jorge A. Militares, industriais e políticos. $O$ entrelaçamento das elites brasileiras - 1930 1984. Brasília: UnB, Dissertação de Mestrado em Ciência Política, 1990, p. 60-1. 
Assim, os militares não negaram peremptoriamente os desejos separatistas do norte goiano. Em 1978, o próprio presidente Figueiredo declarava-se favorável ao projeto emancipacionista, o que segundo a imprensa da capital, teria "conquistado inequívocos resultados eleitorais para o seu partido, a ARENA, em toda a região norte de Goiás"7 . O mesmo presidente, em mensagem ao Congresso Nacional para o ano de 1982, decantava para o norte goiano os benefícios do plano de desenvolvimento integrado da Bacia do Araguaia-Tocantins (PRODIAT). Afirmava que seu governo daria especial atenção ao zoneamento econômico-ecológico da Amazônia legal. ${ }^{8}$

Com efeito, o Estado o principal agente mediador entre as determinações regionais e o espaço nacional. A valorização da terra como negócio de investimentos concentrados, torna a ação geopolítica do Estado fundamental para manter o arcabouço das contradições da expansão capitalista nas regiões periféricas: "atrair e manter a força de trabalho na região sem lhe dar o domínio efetivंo da terra". ${ }^{9}$

O Estado burocrático-militar não sobreviveu apenas porque dispunha da força e de um congresso dócil. A solidez do poder militar nas regiões do país, especialmente naquelas onde os militares testavam a sua geopolítica, diz respeito ao seu papel modernizante a partir da institucionalização dos interesses capitalistas nas novas fronteiras de exploração, como foi o caso do Cerrado e da Amazônia legal. ${ }^{10}$ Ao aceitar-se a hipótese de Stotz, de que "o domínio militar de fato alterou esse país", ${ }^{11}$ caberia perguntar, por outro

7 Jornal de Brasília. Brasília 13 set. 1979. Quem diz esquece, mas quem ouve não perdoa: "iludidos foram os tocantinenses pelo presidente João Figueiredo que declarou ostensivamente, em praça pública, no final de 1978, que a criação do Estado de Tocantins era um compromisso pessoal seu como os antigos anseios da região. Seis se passaram e, como todo o poder que detinha, inclusive o de decurso de prazo na área parlamentar, jamais encaminhou qualquer mensagem ao Congresso Nacional. Se quisesse realmente, poderia tê-lo feito". ROCHA, João. "Desenvolvimento com divisão territorial". In. O Popular. Goiânica, 21 abr. 1985.

8 FIGUEIREDO, João B. Mensagem ao Congresso Nacional. Brasília: Imprensa Nacional, 1982, introdução e p. 73.

9 BECKER, Bertha K. Geopolítica da Amazônia. A nova fronteira de recursos. Rio de Janeiro: Zahar, 1982, p. 231. Uma contundente crítica aos projetos estaduais em Goiás no início da década de 80 consta em SANTILLO, Henrique. Goiás Terras, grilos e dólares. Brasília: Senado Federal, 1981.

10 Para uma visão regional do início do período militar, ver SOUZA, Dalva Maria B. L. D. de. 1964 em Goiás: o Ovo da Serpente (militares e proprietários de terras na gestação da ditadura). Goiânia: UFG, Dissertação de Mestrado, 1990).

11 STOTZ, Eduardo N. As Faces do Moderno Leviatã. In: MELLO, M. A. (Org. 20 Anos de Resistência. Altenartiva da cultura no regime militar. Rio de Janeiro: Espaço e 
lado, até que ponto e dentro de que limites estruturais os militares teriam mudado o Cerrado? E por quê o norte goiano, mesmo recusando, continuou sendo Goiás diante da modernização apregoada? Talvez o discurso federativo dos nortenses nos indique a metamorfose inacabada.

\section{2 - O discurso federativo nortense}

A realização autonomista do norte goiano, concretizada com a assembléia Constituinte (1986-88), tinha fundamentos históricos inegáveis. Estudos recentes procuram demonstrar que o norte do estado de Goiás postulou ciclicamente projetos de divisão do estado para superar o descaso administrativo e o atraso econômico. ${ }^{12}$ Entretanto, julga-se necessário a análise do discurso federativo dos agentes sociais e políticos da regiāo nas décadas de 70 e 80 para melhor caracterizar as suas posturas de classe bem como o conjunto da sociedade regional.

Já na década de 50 afirmava-se textualmente que a classe dirigente regional tinha competência para se autogovernar e governar os outros setores sociais: "na região existe uma elite intelectual que poderá arcar com todas as responsabilidades que pesam sobre os dirigentes e homens públicos de qualquer governo". ${ }^{13}$ Nos anos 60 , o discurso federativo dá a entender que os males políticos e sociais dos nortenses seriam externos, isto é, produzidos por lideranças oriundas além do paralelo 13:

"a politicalha tem sido a nossa madrasta. Tem até hoje se portado no lugar onde deveria ter ficado a verdadeira política da administração. Por isso padece o nosso povo as agruras das ações nefastas dos que falam por nós, dos que nos enganam com a demagogia criminosa, dos que mercantilizam o nosso voto. ${ }^{14}$

Na década de 70, o federalismo arrefece frente ao perigo do inimigo interno e no roldão da ideologia da Segurança Nacional. O norte goiano viveria o milagre econômico no estigma da guerrilha do Araguaia e das

Tempo, 1986, p. 13-28.

12 Ver CAVALCANTE, Maria do E. S. R. O Movimento Separatista do Norte de Goiás -1821-1988. Goiânia: UFG, Dissertação de Mestrado, 1990; COSTA, Célio. Fundamentos para a criação do Estado do Tocantins. Goiânia: Líder, 1982.

Carta de Porto Nacional Resolução da Câmara Municipal de Porto Nacional, 13 out. 1956.

14 MARTINS, Manoel. O drama de um povo. In: O Popular. Goiânia. UB ago.1965. 
operaçōes contra-revolucionárias dos militares destinadas a combatê-la. Associação Tocantinense de Imprensa (ATI) considera um dos seus relevantes serviços prestados a sociedade, a denúncia "às autoridades competentes do incipiente movimento subversivo de Xambioá". ${ }^{15} \mathrm{O}$ discurso autonomista nortense ressoaria no Congresso Nacional cabisbaixo e onisciente ao regime, com lembranças de que o Bico do Papagaio, abandonado e injustiçado, tornara-se violento, e que as lavadeiras das margens do Tocantins, ao baterem as roupas dos ricos, viam as águas incólumes levarem suas energias de mocidade. ${ }^{16}$

O atraso econômico do norte de Goiás visto como condiçāo de subdesenvolvimento do próprio Estado e da ineficiência do seu aparelho fiscal na regiāo. Isso acarreta na década de 80 o que se chamaria de "desenvolvimento deprimido". A conclusão de Costa que é o "processo de desenvolvimento do norte goiano vem se dando em caráter lento, residual e praticamente autógeno". ${ }^{17}$ Tal proposição sugere para o início da década de 80 a seguinte constatação: a autonomia produtiva e econômica do norte era já uma realidade; de fato, a regiāo já arcava com o seu próprio ônus federativo e, no entanto, estava subordinada jurídica e administrativamente a outra região (Centro-Sul de Goiás) como um peso mórbido da inércia do aparelho estatal.

Mas, nem por isso, a essa relativa autonomia sócio-econômica, foram diminuídas as contradições de classe ou foi alavancada alguma medida para a desconcentração da renda regional. Uma intelectual da região assim percebia a realidade social e os signos nortenses na aceleração da história brasileira:

"Há riqueza e luxo. Há pobreza e miséria (...) Vê-se, por fora, a antena do rádio, esticada, sustentada, sobre varas, de lado a lado

15 Associação Tocantinense de Imprensa. Opúsculo monográfico sobre a ATI. Porto Nacional, 1979, p. 12. A guerrilha do Araguaia, em nosso entender, não configura a situação de uma luta de classes. Inobstante a luta ideológica e a repressão militar, os guerrilheiros do $\mathrm{PC}$ do $\mathrm{B}$ que sonharam expandir a revolução a partir do norte goiano e sul do Pará, nem pelo seu idealismo, poderiam representar qualquer expressão operário-camponesa da formação social brasileira da década do milagre econômico. Apesar do silêncio sobre o movimento, existe a versão idealista dos guerrilheiros em MOURA, Clóvis (apres.) Diário da Guerrilha do Araguaia. São Paulo: Alfa-ômega, 1985; e, recentemente, a bem documentada reportagem na revista Veja. São Paulo, Abril, out. 1994.

Discurso do Deputado Federal Siqueira Campos. Câmara dos Deputados. Brasília, $1^{2}$ fev. 1971.

17 COSTA, Célio. Op. cit., p. 59, 90. 
do rancho. La já atrás o 'tuial' de mantimentos, o porco no chiqueiro, as aves no quintal." ${ }^{18}$

A autor demonstra os símbolos do novo, da modernidade chegando e se fixando junto à tradição inexorável do cotidiano e o peso ineludível da imobilidade social. Na verdade, o que se redefinia para a estrutura regional, tal como para a nacional, era mesmo o discurso. E muitas vezes o próprio discurso está imbricado nas mentalidades, que não são o mundo das idéias, mas "o mundo do reflexo profundo das estruturas gerais da sociedade." ${ }^{19}$

No início da década de 80 o norte goiano vive o dilema de ser uma área periférica do próprio Estado e do Brasil e, ao mesmo tempo, atravessa uma conjuntura favorável ao projeto emancipacionista. Potencialmente percebia-se a viabilidade que o discurso autonomista poderia abrir espaço para a obtenção de recursos federais e incremento da infraestrutura regional. Setores interessados e representativos da sociedade nortense fundam, em 1981, a Comissão de Estudos do Norte Goiano (CONORTE) que toma para si o ideário histórico lançado por Teotônio Segurado no início do século XIX. Era uma das grandes metas da comissão:

"viabilizar o aumento da representatividade dos norte-goianos junto aos poderes constituídos independentemente de vínculo partidário ou religioso, valorizando, dessa forma, os candidatos e as lideranças da própria região." ${ }^{20}$

Os setores desvinculados do capital, da terra e da burocracia do serviço público parecem envolvidos pela proposta dominante. As posições populares, tais como sindicalistas e estudantes, vislumbram a autonomia também como uma possibilidade de maior abertura nas decisões do poder regional. Acreditava-se ser possível viabilizar o Tocantins como um Estado-modelo, isto é, sem os "vícios do clientelismo político, do fisiologismo, do empreguismo e do nepotismo, responsáveis pela falência da administração pública em todos os quadrantes do país". ${ }^{21}$

GONTIJO, Ana Braga M.A comunicaçāo no médio-norte goiano. Goiânica: Oriente, 1973, p. 55.

LE GOFF, Jacques. Tempos breves, tempos longos: perspectivas de investigação. In: . O Maravilhoso..., p. 216.

Carta do Tocantins. Documentos do CONORTE. Brasília, 13 maio 1982. In: Revista Estado do Tocantins. Brasília, dez. 1989, p. 14.

21 MARINHO, Jales O Tocantins que queremos. In: Revista... Op. cit., p. 37. 


\section{3 - A autonomia e as elites políticas}

A formação da elite política do norte goiano que participou da campanha autonomista na década de 80 ocorreu na década de 60 e, especialmente, a partir da instituição da Casa do Estudante do Norte Goiano (CENOG). Segundo o seu fundador, Ruy Rodrigues da Silva a CENOG "era um lugar de encontro de jovens ao mesmo tempo um lugar de encontro de propostas, onde se tentava elaborar um projeto alternativo". ${ }^{22}$ Parece claro que a CENOG contribuiu para estimular o surgimento de lideranças estudantis e políticas que se fizeram presentes nos anos da emancipação. Afirma-se também que, com a CENOG, a cidade de Porto Nacional "se consolidou como a capital intelectual dos nortenses. ${ }^{23}$ Preocupada com os destinos do Setentrião, a nova geração era vista como "os deputados extras da região" que iriam redimir "o gigante pobre deitado na riqueza latente". ${ }^{24}$

A CONORTE não deixa de ser a continuação da pregação "desenvolvimentista" desencadeada pelas lideranças estudantis de outrora. Eles agora despontavam como empresários, profissionais liberais e servidores da burocracia federal e estadual no Cerrado goiano. O estatuto da Comissão deixa claro o papel das lideranças na consecucção do objetivo emancipacionista. No artigo terceiro, que define os objetivos da entidade, firma-se que a congregação da população do norte goiano em torno dos ideais nortenses deve ser feita através de suas lideranças, cujo dever é "conscientizá-la da realidade atual, de suas necessidades e de seu potencial humano e econômico". ${ }^{25}$

Entretanto, reconhecia-se que, ainda em 1986, "o movimento pela criação do Tocantins não tinha ressonância na opinião pública e na imprensa". ${ }^{26}$ Isso justificaria uma forte campanha publicitária nos meios de comunicação de massa para popularizar o ideário da emancipação. A comunicação dita de massa foi um dos fatores relevantes para a justificativa do novo Estado. A CONORTE reconhece que "sem ela, provavelmente não se teria alcançado o nível de mobilização que hoje (1989) empolga amplos setores vinculados a emancipação do Norte goiano". ${ }^{27}$

A idéia motriz de que a emancipação equivaleria ao sonho de libertação redimensionada pelas elites políticas locais na década de 80 . Afirma-se

22 Ruy Rodrigues da Silva. Entrevista. In: Revista... O. cit., p. 6. Idem, ibidem.

ROCHA, João Tocantins. A força de um ideal. Goiânia: O Popular, 1989, p. 111-2. Mais dados sobre a CENOG ver a mesma obra, p. 139, 189, 2132289. Jales Marinho. Entrevitsa. Idem, p. 50. Idem, p. 24. 
que a Amazônia legal goiana deve ter reconhecida a sua autonomia "para que seu povo se liberte do guante da opressão, da pobreza e das demais condições geradas pelo abandono e pela injustiça". Assim, os "interesses das oligarquias e das forças colonialistas internas e externas" que têm evitado o emancipacionismo nortense teriam que se submeter ao governo com legitimidade local. Mas, no último parágrafo do então deputado federal Siqueira Campos, estaria subjacente a virtual necessidade do imediatismo do projeto emancipacionista, isto é, possibilitaria "o preenchimento do enorme vácuo de poder, entre Goiânia e Belém, que desampara e prejudica". Era preciso, pois, mais Estado para "a altiva gente morena nortense. ${ }^{128}$

Um estado tocantinense era visto como a alternativa de poder ao "despotismo" da capital Goiânia em relação ao norte. Ao vampirismo administrativo goiano, na expressão de muitos intelectuais, sobrepunha-se a idéia de que o novo Estado, por si só, seria ético, democrático e rico. ${ }^{29}$ aqui percebe-se que a elite cria para si, como de resto para toda a sociedade, um sistema de valores que pretende a sua perenidade histórica. Confirma-se, assim, a hipótese de Duby, de que nesse sistema que residem:

"os princípios de uma ação que pretende animar o futuro do corpo social, onde se enraiza o sentido que toda sociedade atribui a sua história e onde se acumulam as reservas de esperança. Alimenta os sonhos e as utopias (...) para uma idade de ouro de atrativos ilusórios, ou entāo projetados para o futuro, para um porvir que se deseja e pelo qual acontece as pessoas bateremse." ${ }^{30}$

As carências estruturais da região eram vistas como impossibilidades de expansão do capital. A exigência dos representantes dos comerciantes e empresários era para que a emancipação possibilitasse a vocação "natural" da região"

"O Norte goiano está consciente de que nenhum desenvolvimento é alcançado se a busca não se firmar na trilogia infraestrutural: energia e estradas, convergindo-se como ponto de apoio à expansão agropastoril. ${ }^{131}$

28 Discurso do Deputado Federal Siqueira Campos na Câmara do Deputado. BrasíliaDF. 6 ago. 1987.

29 Associação Tocantinenes de Imprensa. Op. cit., p. 11-2.

30 DUBY, Georges. História Social e Ideologia das Sociedades. In: LE GOFF, J., NORA, P. Fazer história. Lisboa: Bertrand, 1977, p. 174.

31 Carta de Tocantins. CONORTE. Brasília-DF, 13 maio 1982, grifo do documento. 
A viabilidade do novo Estado percebida como também a possibilidade para que os "filhos da terra" cheguem ao poder. Poder esse que em Goiânia era inacessível às lideranças nortenses estavam capacitadas para o exercício de mandatários, argumentação de um expressivo intelectual nortense:

Norte de Goiás conta com um quadro de políticos e técnicos capazes e experimentados, para a formação dos quadros governamentais nos poderes Executivo, Legislativo e Judiciário. E essa arregimentação dos filhos ilustres do Norte goiano para compor o seu governo proporcionara a fixação das famílias na região, além de atrair uma gama imensa de investidores da agroindústria que hoje, apesar de tudo, já acredita que o nortense começa a viver um novo tempo de desenvolvimento econômico e social. ${ }^{32}$

Parece um tanto evidente a natureza política do discurso autonomista das elites do norte goiano. O "vácuo de poder" na região e a consciência de que existia lideranças locais competentes para ocupá-lo e que acalentava a perspectiva de outro Estado. Pode-se dizer que se formou na década de 60 , com a CENOG, a consciência de uma "elite em si", para se consolidar na década de 80 a consciência de uma "elite para si", capaz de se autogovernar e governar os agentes sociais e econômicos mais imediatamente a ela dependentes ou circunscritos. Aquela intrigante indagação de Le Goff ganha, na realidade nortense, uma plausibilidade convincente: "a política é ainda a ossatura da História". ${ }^{33}$

\section{3 - TEMPO, MENTALIDADES E SOCIEDADE}

\section{1 - Paradoxos da modernidade}

Apesar do abandono generalizado do Norte goiano pelos poderes públicos, via de regra denunciado pelo discurso autonomista, a regiāo que

32 ROCHA, João. Estado do Tocantins: um projeto viável. In: O Popular. Goiânia, 23 mar. 1985.

33 LE GOFF, Jacques. A Política será ainda a ossatura da História? In: Maravilhoso... Op. cit., p. 221-42. "O reino do político, da política e dos políticos (política teórica, política prática e homens políticos) é portanto o reino da elite, e foi aí que a história política foi buscar a sua nobreza. Fazia parte do estilo aristocrático". Idem, p. 225. grifos do autor. 
integra o vasto espaço da Amazônia legal, sofre, gradativamente, o processo de "integração psicossocial" ao Estado-nação. O controle da informação e da opinião é medida por programas dirigidos a incorporação dos setores sociais à modernização do país. Projetos como o MOBRAL, Randon e RADAM, o uso do rádio e da televisão evidenciam a racionalidade estatal nesse processo ocorrido nos anos 70. Segundo Becker:

"Acumula-se um inventário de informações variadas sobre a região, as quais são canalizadas para o centro político-econômico nacional, incorporando a região ao resto do país; no sentido inverso, difunde-se para ela a ideologia do centro. Asim, a integração psicossocial constitui-se em fator de socialização da população. $^{34}$

Os próprios defensores da autonomia consideravam fundamental a racionalidade político-administrativa para resolver os males regionais. Eles queriam "afeiçoar o mosaico geopolítico nacional a um modelo de redivisão que repare a conformação irracional de algumas unidades da Federação herdada do Brasil-colônia". ${ }^{35}$ Portanto, racionalidade condiz com modernidade e federação. Ao Estado centralizado dos militares, a abertura política pressupõe a redefinição do funcionamento do Estado democratizado. Julgase mesmo que a racionalidade administrativa passa pelos políticos e autoridades locais, estas a encarnação das decisões modernas e ágeis do Estado liberal:

"A descentralização do poder e do progresso volta os olhos atônitos da nacionalidade para os chapadões do interior. (...) $\mathrm{O}$ alargamento das fronteiras agropecuárias da Nação não tem como desviar do Norte do meu Estado. E só se efetivar no estabelecimento de um gerenciamento próprio e de lideranças políticas locais, capazes de romper as nefandas estruturas de miséria, da estagnação e do subdesenvolvimento..$^{36}$

Percebe-se que a ótica da racionalidade político-administrativa vista pelos políticos do Cerrado passa a ser uma relação de crítica e de distância ideológica ao centralismo de Brasília do tempo dos militares. A democracia, como regime representativo de todos os "chapadōes", é entendida como o 
auto-governo e o desabrochar de lideranças identificadas com o desenvolvimento regional. Porém, a prática política no Brasil tem demonstrado que quanto mais localística for a instância do poder, mais perto ela estará da tradição viva, isto é, daquilo que José Honório Rodrigues chamou de "alguma coisa que usada dia após dia, vida após vida, num efeito infindável de sustentação do status-quo". ${ }^{37}$ Por tanto, parodoxal e contraditório será a adoção do discurso liberal enquanto expressão da racionalidade aministrativa e da modernização do Estado.

Nas regiōes periféricas do capitalismo brasileiro, o liberalismo como ideologia dos setores dominantes, funde-se às estruturas de pensamento tradicionais no que concerne aos mecanismos que engendram a própria modernização e alargamento da participação social no processo políticoeleitoral-partidário. $\mathrm{O}$ exaurimento do regime militar cedeu lugar a emergência da democracia liberal representativa. A democratização das intâncias federal, estadual e municipal é um processo multilinear e com não poucas singularidades regionais. O caso goiano é elucidativo para especificar as contradições e os paradoxos do liberalismo modernizante. Cresce na década de 80 no Cerrado aquilo que se poderia designar como um liberalismo de variante populista cujo discurso pauta-se pelo anti-status-quo, apelo ao povo, e não às classes, desconfiança dos políticos tradicionais e um antiintelectualismo voltado ao pragmatismo assim como ao voluntarismo político. ${ }^{38}$

As dimensōes estruturais da realidade regional e os efeitos psicossociais da modernização de cunho liberal tendia, inevitavelmente, a criar um abismo entre as aspirações da população nortense e as reais possibilidades por parte do poder público de satisfazê-las. Mesmo ao se contrapor aos políticos tradicionais nível nacional, o liberalismo regional não se desvincula de seus interesses de classe. E apesar de seu forte apelo pelo poder localístico, tal liberalismo não chega a oferecer uma sedução "modernal" aos setores médios e burocráticos que se alastram no aparelho estatal regional. Ver-se-á, a seguir, até que ponto o aparecimento de posturas e de discursos modernizantes não prescindem das antigas formas e pouco mutáveis estruturas coronelísticas regionais.

37 RODRIGUES, José H. Filosofia e história. Rio de Janeiro: Nova Fronteira, 1981, p. 34.

38 DEBERT, Guita G. Ideologia e populismo. São Paulo: Queiros, 1979, p. 12. Um exemploL "espero ardentemente que, ao raiar o no Estado, sua gente se mobilize e não permita nunca que ali se estabeleçam feudos políticos e oligarquias. Que todos se comprometam verdadeiramente com o processo democrático. Discurso do Governador Henrique Santillo. Op. cit., grifo meu. 


\section{2 - O coronelismo tardio}

Como instituição política e hegemônica do processo eleitoral, o coronelismo viveu o seu apogeu na chamada República Velha (1889-1930). O predomínio das oligarquias do Sul-Sudeste ocasionou para a regiāo do Cerrado as limitaçōes intrínsecas a que estavam submetidos os seus próprios coronéis. Campos alude ao "periferismo goiano", isto é, o pouco interesse federal com a política local e os problemas sociais goiano. ${ }^{39}$

A urbanização e a industrialização são fenômenos desreguladores do domínio coronelista. Entretanto, eles constituem mudanças não-espontâneas dos agentes sociais e de complexa diversidade regional que, se enfraquecem o poder do coronel, nem por isso são suficientes para eliminá-lo da arqueologia política brasileira. Impertinente ao tempo, o coronelismo é uma das formas adotadas pelo mandonismo local no Brasil com algumas variações regionais no decorrer da República. ${ }^{40}$ Do ponto de vista sociológico, entende-se que é uma afirmação anormal do poder privado, caracterizado por uma elite controladora do poder político, social e econômico encarnada no proprietário rural, ocasionalmente no burocrata, no comerciante ou no profissional liberal do interior do Brasil. Há uma dificuldade de separação entre o domínio do círculo familiar e o domínio da coisa pública. Ainda na década de 60 afirmava-se a preponderância do Estado patrimonial-coronelístico nos destinos da região nortense:

"O povo desta imensa zona territorial cônscio da malevolência de uma oligarquia ultrapassada que, se algo de bom fez para a região, foi estagnar o seu progresso e desenvoluimento em proveito de um reduzido número de privilegiados e perpétuos 'coronéis' das barganhas políticas. ${ }^{41}$

CAMPOS, F. Itami. Coronelismo em Goiás. Goiânia, UFG, 1987, p. 45 e segts. Outra importante obra para o coronelismo na região é a de PALACIN, Luis. Coronelismo no Norte Goiano. São Paulo, Edições Loyola, 1990. Também fundamental pela documentaçāo e inserindo o tema na História Social é o estudo de COSTA, Lena C. B. F. Um coronel do Meio-Norte. In: Arraial e Coronel. São Paulo: Cultrix, 1978, p. 107-206. Vale do São Francisco. Ver Dicionário de Ciências Sociais. São Paulo: FGV-MEC, 1987, p. 164-5, 274-76. 
É de se perguntar se a centralização política no pós-64 e a supremacia do Executivo sobre o Legislativo na década de 70 não eliminou o poder do patronato da terra nos Estados periféricos? O certo é que a experiência coronelista, direta, pura ou transmutável, permitiu o aprimoramento de recambiantes vínculos de fidelidade e adesão políticas permeadas pela lógica franciscana do "é dando que se recebe" - note-se que se trata de um mote altruísta e democratizante - no contexto do liberalismo vigente. A política de clientela continua em regiōes tardiamente urbanizadas, sendo imponente ou, no mínimo, anda lado a lado com a política ideológica nos centros urbanos mais cosmopolitas.

Inicialmente refratários à política tradicional-populista, muitos militares e burocratas favorecidos pelo regime de excessão, acabaram transformando-se diante da pobreza do Cerrado, em verdadeiros coronéis-coronéis, ou seja, "o homem que protege os amigos e persegue os inimigos e desafetos". Ainda na década de 80 , um intelectual nortense cobrava um governante que não tivesse "os vícios do clientelismo político, do fisiologismo, do empreguismo e do nepotismo". ${ }^{42}$ Seria um desabafo contra a permanência do cotidiano coronelista na região? Acaso a modernização, e mesmo o novo Estado, por si mesmos, concretizariam a política ideológico-partidária? Ora, a política é a ação dos homens, e cada agente social, independente de classe, "é um ser histórico, gerado num padrão criado pelo tempo, e inconsciente de que o próprio eu está carregado de perigos" ${ }^{43} \mathrm{~A}$ bem da verdade, a própria burocracia brasileira, enquanto estamento diferenciado, antes de destruir, consolidou o sistema patrimonialista para um capitalismo politicamente orientado e pouquíssimas vezes liberal-competitivo. Assim, no dizer de Faoro, "a pressão da ideologia liberal e democrática não quebrou, nem diluiu, nem desfez o patronato político sobre a nação". ${ }^{44}$ Portanto, não se poderia esperar que o Norte goiano estivesse liberto da lei de ferro das oligarquias.

\section{3 - Tipologia sociológica tocantinense}

A estrutura social permite-nos compreender as relaçōes de interdependência, as sincronias e as diacronias que os grupos sociais mantém entre si nos diversos momentos históricos de sua existência material e mental. É no

42 Ver nota 19.

43 RODRIGUES, José H. Op. cit., p. 89.

44 FAORO, Raymundo. Os donos do poder. Formaçāo do patronato político brasileiro. v. 5. ed. Porto Alegre: Globo, 19798. v. 2, p. 747. 
espaço regional que se concretiza os mecanismos de inserção social bem como as especificidades da conjuntura social. ${ }^{45}$

Apesar do "esquerdismo" exagerado das análises sócio-econômicas sobre o período militar, não se pode creditar ao golpe de 64 as marcas mais profundas da estrutura social brasileira. Quando os militares e a tecnocracia liberal tomam o Estado em 1964 defrontam-se com uma complexidade regional e com uma diversidade temporal de desenvolvimento econômico cruciais ao capitalismo desenvolvimentista. O populismo como tal, deixava a política e o domínio público nos estados periféricos aos remanescentes do coronelismo oligárquico-familiocrático. Quando se arrisca a uma classificação das elites regionais para a década de 60 , a postura mais real parece ser a de Dalva Souza:

"Em Goiás não há como pensar senão na burguesia proprietária de terras como classe dominante que, se começava a buscar interesses de mais longo prazo, guardava ainda fortes resquícios oligárquicos. Há, evidentemente, uma comercial que, no entanto, permanece vinculada ou subordinada aos interesses agrários". ${ }^{46}$

Segundo a mesma autora, os proprietários fundiários ao mesmo tempo que apoiavam o golpe contra João Goulart, ficaram temerosos do Estatuto da Terra do governo Castelo Branco. Daí a aproximação tácita do patronato rural regional com a linha dura dos militares entre 1966 a 1974. Até o enfraquecimento do regime militar no início da década de 80 , as soluções e conveniências viáveis para o fosso criado entre o Estado centralizador e modernizador e as elites regionais periféricas foram sempre postergadas em nome da Segurança Nacional. No entanto, assim como na sociedade civil, o establishment militar já apresentava cisōes graves no encaminhamento da questāo agrária e da pressão operário-urbana em virtude da quebra do encanto do milagre. ${ }^{47}$ Nesse sentido é que o pais se volta para a última fronteira agrícola disponível no cerrado brasileiro: o norte goiano. O Setentrião, carinhosamente chamado pelos velhos intelectuais da terra, debate-se pela aceleração da História. Entoa-se o cântico da modernidade, da urbanização e da industrialização. A estrutura social dirá mais do que qualquer discurso.

45 SOUZA, Itamar. Migrações internas do Brasil. Petrópolis: Vozes, 1984, p. 33.

46 SOUZA, Dalva Maria B.L.D. de Op. cit., p. 47.

47 Idem, p. 120. 
Célio Costa, escrevendo nos anos 80 , constatou o acelerado processo de urbanização no norte goiano, com um aumento da indústria e da pecuária e uma diminuição relativa da agricultura. Eis, então, o paradoxo das permanências agraristas na mentalidade regional: o aumento do conflito em terras litigiosas, o quadro agrário conturbado e o predomínio do latifúndio passam a ser os principais e irremovíveis entraves à modernização do setor rural assim como dos demais setores produtivos. ${ }^{48}$ Assim, o que restou para os pequenos lavradores, os trabalhadores assalariados e os garimpeiros ocasionais, foi a rudimentaridade da modernização tecnocrática. A ascensão social na hierarquia do novo paraíso estaria reservada aos que chegavam do purgatário, vale dizer, do centro dinâmico do capitalismo nacional, especial mente de empresários sulistas. ${ }^{49}$

A concretização da BR-153 (Belém-Brasília) nos anos 60 e o seu definitivo asfaltamento na década de 70 , possibilitou ao norte goiano a chegada de novos contingentes sociais dos mais diferentes estados da federação. Os contingentes sulistas são de fato expressivos no Cerrado nos últimos vinte anos. Desde a década de 40, por exemplo, fazia parte da política getulista para incrementar a Marcha para Oeste. Grande leva de gaúchos aportavam então no Mato Grosso como "os bombachudos" - pelo uso da vestimenta e com sentido pejorativo - segundo a historiadora Nadir Mendonça. É na década de 60 o Cerrado passou a ser a grande atração para os migrantes de todo o Brasil, e especialmente para os sulistas segundo o estudo da autora mcncionada. ${ }^{50}$

As terras disponíveis e a política estatal de incentivos fiscais permitiram a migração de grandes capitais e empresários da agroindústria. No seu bojo migraram também a classe média rural que no setentrião poderiam se tornar latifundirários pelo baixo custo da terra comparado à regiāo de década de 70 para as cidades do Norte Goiano e Alto-Araguaia-Tocantins 2.863 paranaenses, 773 catarinenses e 3.808 rio-grandenses (gaúchos). As cidades do atual Tocantins que mais receberam esses migrantes foram Peixe, Gurupi, Guarai, Formoso do Araguaia, Araguaina, Cristalândia, Alvorada e Crixás. Cf. IBGE. Censo Demográfico 1980. Goiás. v. 1, tomo 4. Rio de Janeiro, 1982. 
origem, os operários qualificados do sudeste, os trabalhadores sazonais do Maranhão e do Piauí, cuja proximidade favorece-os em relação à São Paulo, e os servidores das classes médias urbanas na busca de novos empregos e melhores condições salariais e de vida. O crescimento das cidades do norte goiano e do atual Tocantins é a expressão mais cabalmente visível dessa situação migratória. ${ }^{51}$ Esse processo tende a acentuar a participação, importância e reivindicações daquilo que se poderia designar de grupos médios regionais, quebrando com isso, a estrutura binária da sociedade nortense, isto é, a dicotomia entre o patronato da terra hegemônico e os pequenos lavradores, meeiros e agregados ainda excluídos da modernidade. ${ }^{52}$

A emergência dos setores médios urbanos e suas correlatas exigências de salários, moradia, educação e transportes vislumbra para o novo Estado a perspectiva para mudar o que deve ser mudado na exata proporção dos limites do liberalismo modernizador vigente. Mas, independente da vontade do poder constituído e da ideologia dominante, a migração faz com que o Estado receba novas formas de comportamento e de novos valores mentais e sociais do Sul e do Sudeste, já que a sua cultura anterior era predominantemente norte-nordestina. Os novos contingentes sociais, por sua vez, sofrem o impacto da cultura "nortense" que o Cerrado lhes acena e mesmo lhes impõe. É certo que a migração considerável para o Estado tem como condição precípua o sonho da propriedade, da ascensão social e do trabalho permanente, o que está se tornando cade vez mais difícil. Entretanto, permanece ilusão do último Eldorado brasileiro que se debate entre dois caminhos: franja da exuberância natural da Amazônia oriental preservada ou fragmento dilacerado de um capitalismo voraz? Sintomática a frase de um conhecedor da região: "o mundo não pára e os homens, erradamente ou acertadamente, não deixam de trabalhar". ${ }^{53}$

51 IBGE. Censo Demográfico... Op. cit., p. 228-30, PRODIAT - Projeto de Desenvolvimento Integrado do Araguaia-Tocantins. Desenvolvimento urbano na Regiäo do Prodiat. Ministério do Interior. Brasília, ago. 1985, p. 8 e ss.

52 Em recente pesquisa, Liliana P. L. Sepúlveda Pereira constatou que, apesar do recrudescimento de ódios regionais e da penetração empresarial no Bico do Papagaio, a dialética imprevisível da História esboça a emergência de "um setor médio rural na região, ou seja, a batalha do Bico do Papagaio chegará ao fim com o surgimento de uma camada de pequenos proprietários rurais, ou posseiros hoje transformados e em via de se transformarem em pequenos proprietários". PEREIRA, Liliana L. S. Os conflitos pela terra na regiäo do Bico do Papagaio (Tocantins) na década de 80 . Goiânia: UFG, Dissertação de Mestrado, 1990. MARANHÃO, Othon. Setentrião Goiano. 2. ed. Brasília: Senado Federal, 1990, p. 


\section{CONCLUSÃO}

A narrativa do presente trabalho, assim como as fontes por ela mencionada nos permite evidenciar algumas observaçōes conclusivas para a história recente do setentrião e que gestou o Estado do Tocantins.

A representação política das classes sociais no aparelho de estado é incompatível com o projeto de modernização do norte goiano, pois o processo eleitoral permaneceu vinculado à política clientelista com postura mínima para uma política de caráter racional-partidário-ideológico. O grau de permanência do coronelismo nas estruturas de poder regional foi pouco abalado com a militarização do Estado nacional e com os projetos federais na região; assim como a modernização estatal teve efeitos diacrônicos nos padrōes sócio-econômicos regionais.

Nas décadas de 70 e 80 abriram-se possibilidades infraestruturais para a emergência dos setores médios urbanos no norte goiano. Colaborou para isso o projeto estatal de integração da Amazônia legal à Segurança Nacional e a mentalidade difundida nas regiōes centrais do capitalismo brasileiro de que, além do paralelo 13, apresentava-se aos desbravadores modernos, um novo Eldorado para a nação. Finalmente, poder-se-ia argumentar que essa conjuntura foi favorável ao processo emancipacionista consubstanciado no final da década de 80 .

10. Acaso o velho intelectual nortense nāo teria dado uma "espiadela" em algum texto de Marx? "O trabalho é condição eterna do homem" já dizia no século XIX o feroz crítico do capitalismo e, mais ainda: "a maneira como os indivíduos se manifestam sua vida reflete exatamente o que eles são. $\mathrm{O}$ que eles são coincide, pois, com sua produção, isto é, tanto o que eles produzem quanto com a maneira como produzem." MARX, Karl, ENGELS, Friedrich: A ideologia alemã. São Paulo: Martins Fontes, 1989, p. 13. 